\title{
Alternatif Fındık Kurutma Sitemlerinde LED Renk Sıcaklığı ve Mesafenin Kuruma Süresi ve Ortam Sıcaklığına Etkisinin Deneysel İncelenmesi
}

\author{
${ }^{1}$ Mithat Akgün ve ${ }^{* 2}$ Levent Kandemir \\ *1 Fen Bilimleri Enstitüsü, Yenilenebilir Enerji Bölümü, Ordu Üniversitesi, TÜRKIYYE \\ *2 Fen Bilimleri Enstitüsü, Yenilenebilir Enerji Bölümü, Ordu Üniversitesi, TÜRKIYYE
}

\section{Özet}

Gıdaların uzun süreli ve ekonomik olarak korunması kurutma sayesinde mümkündür. Geleneksel ve en ekonomik gıda kurutma yöntemi güneşte kurutma olsa da değişen iklim şartları, kuruma süresi ve gıda özellikleri açısından bakıldığında güneşte kurutmanın birçok dezavantajı mevcuttur. Bu dezavantajları ortadan kaldırmak için farklı mekanik kurutma sistemleri geliştirilmiş ancak bu sistemler de üreticiler ve sanayiler tarafından yeterince kabul görmemiştir.

F1ndığı daha kısa sürede g1da özelliklerini koruyarak kurutacak, hijyenik ve ekonomik bir LED' li fındık kurutma sistemi tasarlanarak imalatı gerçekleştirilmiştir. LED ile fındık arasındaki mesafenin değişimi ve fındık boyutunun fındığın kuruma süresine etkileri ortaya konulmuştur. Mesafe artışına bağlı ışınım etkisinin ortam sıcaklığına ve findık iç sıcaklığına etkileri ölçülmüştür. LED' li sistemde kurutulan findık, etüvde ve güneşte kurutulan findığın kuruma süreleri ile de karşılaştırılmıştır.

Doğal taşınımda fındık ile LED arasındaki mesafe $5 \mathrm{~mm}$ ve $\varnothing 16-17 \mathrm{~mm}$ boyutundaki findığın güneşte kurutma (4080 dakika) ile etüv, $6500 \mathrm{~K}, 4000 \mathrm{~K}, 3000 \mathrm{~K}$ ' de kurutma karşılaştırıldığında findik, sirasıly \%50,8 (2010 dakika), \%73,5 (1080 dakika), \%77,9 (900 dakika) ve \%82,4 (720 dakika) daha kısa sürede kurumaktadır. Fındıkla LED arasındaki mesafenin artışınının etkisi en belirgin $4000 \mathrm{~K}$ renk sıcaklığında gerçekleşmiş olup; $5 \mathrm{~cm}$ ve $10 \mathrm{~cm}$ mesafelerdeki kütle kayıpları $15 \mathrm{~cm}$ mesafeyle karşılaştırıldığında sırasıyla \%33 ve \%29 daha kısa sürede findık kurumuştur. Fındık boyutuna bağlı en kısa kurutma süresi $3000 \mathrm{~K}$ renk sıcaklığı ve $5 \mathrm{~cm}$ için 840 dakika ile Ø14-15 mm boyutlu findıkta gerçekleşirken, en uzun kuruma süresi $6500 \mathrm{~K}$ renk sıcaklığı ve $15 \mathrm{~cm}$ mesafe için $\varnothing 18 \mathrm{~mm}$ ve üstü boyutlu findıkta 1680 dakika olarak gerçekleşmiştir. Üç farklı LED renk sıcaklığı için fındık boyutu arttıkça kuruma süresi de artmıştır.

Anahtar Kelimeler: Kütle transferi, Findık kurutma, LED

Experimental Investigation of the Effect of LED Color Temperature and Distance on Drying Time and Ambient Temperature in Alternative Hazelnut Drying Systems

\section{Abstract}


Long-term and economic protection of food is possible thanks to drying. Although, traditional and the most economical food drying method drying in the sun, drying in the sun has many disadvantages in terms of changing climatic conditions, drying time and food properties. Different mechanical drying systems have been developed to overcome these disadvantages, but these systems have not been sufficiently accepted by manufacturers and industries.

A hygienic and economical LED nut drying system that will dry the hazelnut in a shorter time while preserving its food properties has been designed and manufactured. The variation of distance between LED and hazelnut and effects of hazelnut size on drying time of hazelnut were investigated in this study. Also, the effects of the radiation effect due to distance increase on ambient temperature and hazelnut internal temperature were measured. The dried hazelnuts in the LED system are also compared with the drying times of the nuts dried in the oven and in the sun.

In natural convection, for distance of LED-nut is $5 \mathrm{~mm}$ and $\varnothing 16-17 \mathrm{~mm}$ size of nut, comparing the drying of the hazelnut in the sun (4080 minutes) with the oven, $6500 \mathrm{~K}, 4000 \mathrm{~K}$ and $3000 \mathrm{~K}$, the hazelnuts were dried shorter time $50.8 \%$ (2010 minutes), $73.5 \%$ (1080 minutes), $77.9 \%$ (900 minutes) and $82.4 \%$ (720 minutes), respectively. The effect of the increase in the distance between the hazelnut and the LED was most pronounced at a color temperature of $4000 \mathrm{~K}$; When the mass losses at $5 \mathrm{~cm}$ and $10 \mathrm{~cm}$ distances were compared to the $15 \mathrm{~cm}$ distance, the drying of nuts were took shorter time in $33 \%$ and $29 \%$ respectively. The shortest drying time, depending on the size of the hazelnut, took place at $3000 \mathrm{~K}$ color temperature and 840 minutes for $5 \mathrm{~cm}$ distance and Ø14-15 $\mathrm{mm}$ size nuts. The longest drying time was 1680 minutes at $6500 \mathrm{~K}$ color temperature for $15 \mathrm{~cm}$ distance and $\varnothing 18 \mathrm{~mm}$ over size nuts. Consequently, as the size of the nuts increased for three different LED color temperatures, the drying time also increased.

Key words: Mass transfer, drying of hazelnut, LED

\section{Giriş}

Dünya nüfusunun hızlı artışıyla birlikte gıdaya olan talepte artmış ve gıdanın üretimimi kadar gıdaların saklanmasıda önemli bir hale gelmiştir. Gıdaların saklanmasında çok farklı yöntemler olsada bu yöntemlerin seçimi; gıda sağlığı, kalitenin korunması, saklama süresi, enerji maliyetleri ve depolama ortamının boyutları gibi bir çok parametreye bağlıdır.

Meyve ve sebzelerin uzun süre bozulmadan saklanmasında yetiştirilen ürünlere bölgenin iklim şartlarına, coğrafyasına, insanların damak tadına ve sosyoekonomik durumuna göre çok farklı saklama yöntemleri geliştirilmiştir.

Dondurarak veya soğuk depolama, pekmez veya pestil yapımı ile saklama, turşu yapımı, tütsüleme, baharatlama ve kurutarak gidalar saklamaktadır. Kurutma; daha büyük çapta ürünün saklanması, kurutma maliyetinin azlığı, depolama ve nakliye kolaylığından dolayı binlerce yıldır diğer yöntemlere göre avantajlı konumdadır. Ancak geleneksel kurutma yöntemi olan güneşte kurma tüm dünyada ekonomik açıdan cazipliğini korusa da gıda özelliğinin korunması, kuruma süresinin uzaması, hijyenik bir kurutmanın sağlanamaması ve en önemlisi artan talebi karşılamada yetersizliği dolayısıyla gıda sanayisi için kısa sürede, ucuz maliyetli kurutma yapacak ürün türlerine bağlı çok faklı kurutucular imal etmişlerdir. 
Türkiye'nin en önemli tarımsal ihraç ürünü olan fındık, Karadeniz sahil şeridinde yetiştirilmekte olup, fındık hasat sezonu olan ağustos - eylül aylarında bölge oldukça yağışlıdır. Bu dönemde findığın hasat edilmesi ve geleneksel yöntemle toprağa serili olarak Güneşte kurutulması büyük bir problemdir. Fındığın Güneşte kurutulması sırasında uzun süreli yağmur yağması dolayısıyla fındığın kurutma süresinin uzamasına, işçiliğin ve maliyetin artmasına sebep olmakta, yere serili fındığın toprak ile teması ve dış etkilere açık olması (toz, toprak, kuş pisliği) nedeniyle patojen, mikroorganizma ve mikrobiyal bozulmalar, mikrobiyal toksin kaynaklı hastalıklar dolayısıyla kalite kayıplarına ve hijyen problemine sebep olmaktadır. Uygun olmayan üründen dolayı hem üretici ve findık işleyen firmalar hem de milli ekonomi önemli ölçüde zarar etmektedir.

Geleneksel yöntemle yapılan kurutmanın mahzurlarını ortadan kaldırmak için findığın kimyasal ve biyolojik yapısını bozmayan, kurutma süresini kısaltan ve enerji maliyetini düşüren mekanik fındık kurutma sistemleri imal edilmiş, bu konuda bilimsel birçok çalışma ortaya konulmuştur.

Bıçakçı M., çalışmasında havalı güneş kollektörü destekli, fındık kurutma makinesi prototipi geliştirmiş olup, yaptığı çalışmalar neticesinde Ağustos ve Eylül ayları için Trabzon ve civarına en uygun kollektör eğim açısını 30 derece olarak belirlemiştir. Ayrıca, havadaki bağıl nemin kollektör öncesi düşürülmesi neticesinde, kurutma süresini kısalacağını, dolayısıyla daha fazla ürün kurutulmasının mümkün olabileceğini ifade etmiştir[1].

Demirtaş, fndık kurutma şartlarının belirlenmesi isimli doktora çalışması için laboratuvar şartlarında kurduğu deney düzeneğinde; ağırlıklı olarak 25, 30, 35, 40 ve $45^{\circ} \mathrm{C}$ olmak üzere beş farklı sıcaklık, 0.2, 0.3, $0.6 \mathrm{~m} / \mathrm{s}$ olmak üzere üç farklı hava hızlarında ve kurutma havasının 0.45 , $0.55,0.60$ ve 0.70 olmak üzere dört farklı bağıl neminde fındık kurutma deneyleri yapmıştır. Yaptığı çalışmalar neticesinde en iyi kurutma havası sıcaklığının $35-40{ }^{\circ} \mathrm{C}$ ve hızının ise $0.3 \mathrm{~m} / \mathrm{s}$ olduğunu tespit etmiştir[2].

Olgun ve Rzayev, fındığın güneş enerjisi ile kurutulmasını farklı üç sistemde incelemiştir. Dalından yeni toplanarak, zurufundan ayrılmış nem oranı yüksek findıkları; çadır, dolap ve kabinet tipi olmak üzere üç farklı güneş enerjili kurutma sisteminde kurutmuşlardır. Çalışma sonuçlarını açık havada yapılan doğal kurutma sonuçları ile karşılaştırmışlardır. Yapılan çalışmalarda açık havada doğal şartlarda 82 saatte, kabinet tipli kurutucuda yaklaşık 50 saatte, ek 1sitıcı kullanılması durumunda 28 saatte, çadır tipi kurutucu ile 73 saatte ve ek 1sitıc1 kullanılmamış olan dolap tipi kurutucu ile 72-76 saat arasında kurutmuşlardır[3].

Aktaş, ülkemizin önemli ihraç ürünlerinden birisi olan findığın uluslararası standartlarda kurutulamamasının pazar payı kayıplarına yol açtığını belirten araştırmacı, çalışmasında 1sı pompası destekli PID kontrollü bir kurutucunun tasarım ve imalatını yapmış. İmal ettiği 1sı pompalı kurutucuda, kurutma havası sıcaklık ve hızlarını $50{ }^{\circ} \mathrm{C}$ için $0,25 \mathrm{~m} / \mathrm{s}, 45{ }^{\circ} \mathrm{C}$ için 0,32 $\mathrm{m} / \mathrm{s}$ ve $40{ }^{\circ} \mathrm{C}$ için $0,38 \mathrm{~m} / \mathrm{s}$ alarak fındıkları sırasıyla 24,27 ve 30 saatte kurutarak test ve enerji analizlerini yapmıştır[4].

Akgün ve ark., yaptıkları deneysel çalışmada, daha az enerji ile kısa sürede ve gıda özelliklerini koruyacak şekilde fındığın mekanik kurutulmasını sağlamak için sıcak beyaz (sarı) $3000 \mathrm{~K}$ renk sıcaklığına sahip LED 'li bir tünel tipli kurutma sisteminin tasarım imalatını yaparak kullanmışlardır. Kurulan sistem içerisinde findık iki farklı boyut (14-15 mm, 16-17 mm) ve 
dört farklı hava hızında $(\mathrm{v}=0 \mathrm{~m} / \mathrm{s}, \mathrm{v}=0,5 \mathrm{~m} / \mathrm{s}, \mathrm{v}=1 \mathrm{~m} / \mathrm{s}$ ve $\mathrm{v}=1.5 \mathrm{~m} / \mathrm{s})$ kurutulmuştur. Ayrıca karşılaştırma yapabilmek için fındıkları, fırın ve güneşte de kurutmuşlardır[5].

Malekjani ve ark., mikrodalga ile konvektif kurutmanın etkin bir kurutma yöntemi olarak, fındıkların kurutma kinetiği üzerine etkilerini incelemişlerdir. $40^{\circ} \mathrm{C}, 50^{\circ} \mathrm{C}$ ve $60^{\circ} \mathrm{C}$ olmak üzere üç farklı sıcaklık ve 0, 450 ve $900 \mathrm{~W}$ güç seviyelerinde yapmış oldukları deneylerde nem oranı ve findıkların sıcaklıklarını kaydetmişlerdir. Yapılan deneyler; kurutma havası sıcaklığına oranla, mikrodalga gücünün daha baskın olduğunu göstermiştir. Ayrıca kurutma işlemi sırasında nem değişikliklerini tahmin etmek için matematiksel modelleme yapmışlardır[6].

Giraudo ve ark., tasarladikları kurutucu ile laboratuvar ortamında, farklı kurutma havası koşullarında (sıcaklıklar: $20^{\circ} \mathrm{C}, 35^{\circ} \mathrm{C}$ ve $50{ }^{\circ} \mathrm{C}$, nispi nemlilik:\%20, \%40, \%60; hava akımı: 0,5 m/s) 6 farklı fındık türünün bazı özelliklerindeki (çap, hacim, ağırlık, yoğunluk, kabuk kalınlığı, şekil indeksi, boş hacimsel çekirdek ve kabuk) değişimleri matematiksel incelemişlerdir. Çalışma sonunda fındıkların ele alınan özelliklerinin endüstriyel alanda sonuca ulaşmak için yeterli olmadığı sonucuna varmışlardır. Çalışmalarını benzer çalışmalar için ön çalışma olarak nitelemişlerdir [7].

Turan, üç farklı Ordu findık çeşidini (tombul, palaz ve levant kalite) $45^{\circ} \mathrm{C}$ ve $50{ }^{\circ} \mathrm{C}$ 'de kurutma makinesi ile, açık havada ise beton ve çim zeminde güneşte kurutmak suretiyle, kimyasal özelliklerindeki değişlikleri tespit etmeye çalışmıştır. Kurutulmuş fındıkların protein, lipid ve nem içeriği, su aktivitesi, serbest yağ asidi (FFA), peroksit değeri (PV), rancimat değeri (RV) ve yağ asidi bileşimlerine yönelik analizlerinde beklediği üzere, tekli doymamış yağ asidinin (MUFA) ana yağ asidi grubu olduğunu gözlemlemiştir[8].

$\mathrm{Bu}$ çalışmanın amacı bölgenin iklim koşulları ve coğrafi koşullarından kaynaklanan findık kurutma problemini daha kısa sürede, gıda özelliklerini koruyarak, ekonomik ve üreticilerin tercih edebileceği yeni bir kurutma metoduyla çözmek. Bunu gerçekleştirmek amaciyla üç farklı renk sıcaklığına sahip LED’in kullanıldığı bir kurutma sistemi tasarlanarak prototipi imal edilmiş, fındık kurutma deneyleri bu sistemde gerçekleştirilmiştir.

\section{Materyal ve Yöntem}

$\mathrm{Bu}$ deneysel çalışmada Giresun ilinde yetişen tombul (Giresun yağlısı) findık "Corylus Avellana L. " kullanılmıştır. Dalından toplanmış taze findıklar zaman kaybetmeden zuruflarından ayrıldıktan sonra elek yardımıyla üç farklı çap aralığında (Ø14-15 mm, Ø 16-17 mm, Ø $18 \mathrm{~mm}$ ve üstü) boyutlandırılmış ve findıkların başlangıç nemi Mettler Toledo marka nem ölçüm cihazıyla ölçülerek yaş fındığın ortalama nem oranı \%33 olarak belirlenmiştir. Aynı zamanda bu nem oranında sabit tutabilmek amacıyla, findıklar boyutlarına göre vakumlanarak etiketlenmiş ve zaman kaybetmeden soğuk hava deposunda koruma altına alınmıştır.

Tombul findık, Güneşte, Etüvde ve LED'li kurutma sisteminde kurutulmuştur. LED'li kurutma sisteminde üç farklı renk sıcaklığına $(3000 \mathrm{~K}, 4000 \mathrm{~K}, 6500 \mathrm{~K})$ sahip LED’ler kullanılmıştır. LED'li kurutma sisteminde LED ile findık arasındaki mesafe $5 \mathrm{~cm}, 10 \mathrm{~cm}$ ve $15 \mathrm{~cm}$ olup, 33x33 cm tepsi alanına sahip kurutma kabinin şematik görünüşü Şekil 1 'de verilmiştir. 
Fındık kurutma için güneşin öğle saatlerinde yaydığı 1şık şiddetine eşdeğer bir aydınlatmaya ihtiyacımız olduğunu kabul ederek, çalışmalarımızda LED renk sıcaklığını gün 1şığı beyazı civarındaki renk sıcaklığına sahip LED’ler (3000 K, $4000 \mathrm{~K}$ ve $6500 \mathrm{~K})$ seçilmiştir. Bu LED’lerin özellikleri Tablo 1'de verilmiştir.

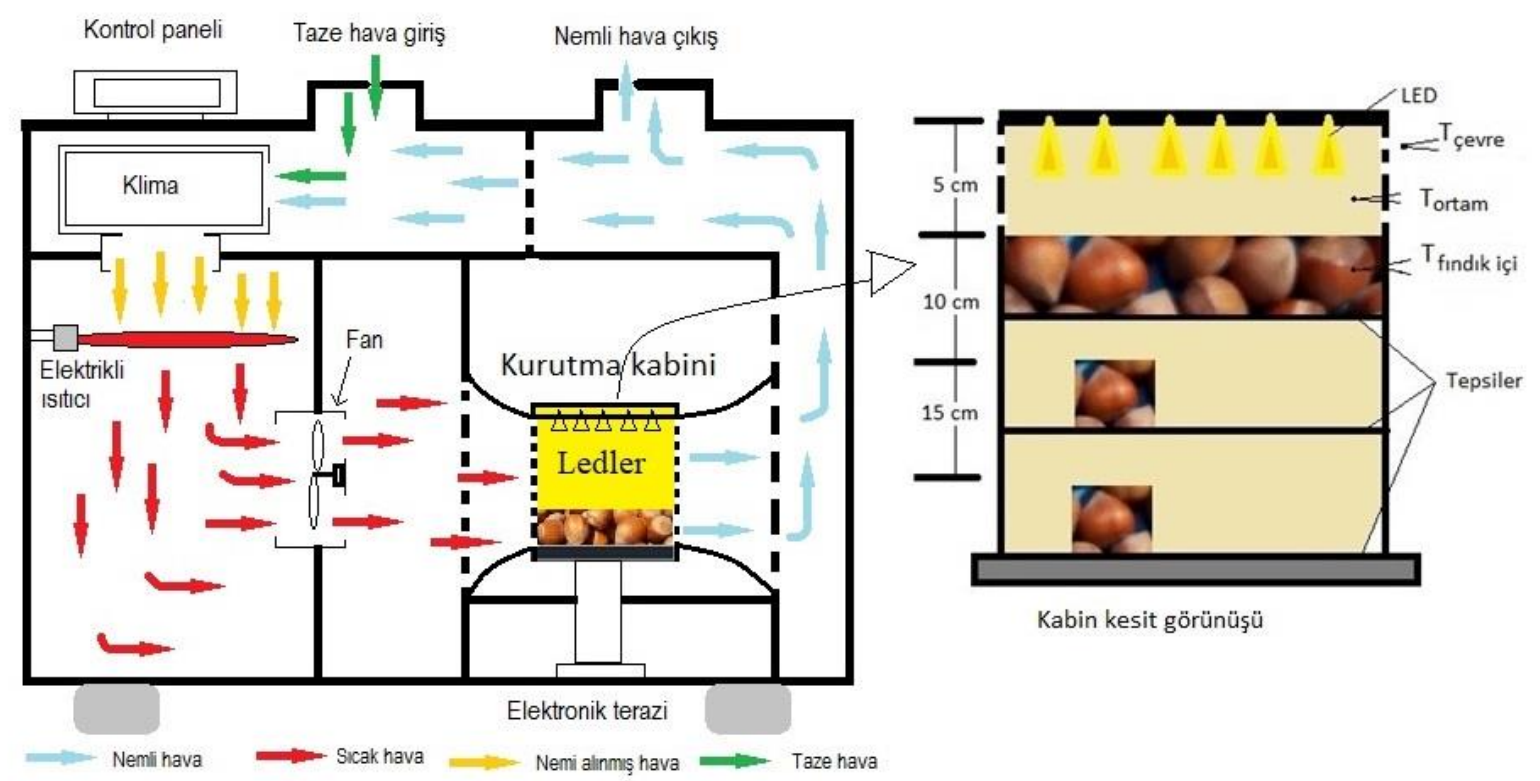

Şekil 1. LED’li tünel tipli kurutma sisteminin şematik görünüşü

Tablo 1. Kullanılan LED’lerin özellikleri

\begin{tabular}{llcl}
\hline İlişkili Renk & Işık & Gerilim & Güç \\
Sıcaklığı & Akısı & (V) & (W) \\
\hline $3000 \mathrm{~K}$ & 11520 & 12 & 96 \\
$4000 \mathrm{~K}$ & 11529 & 24 & 94,5 \\
$6500 \mathrm{~K}$ & 11760 & 12 & 84 \\
\hline
\end{tabular}

10.000 lümen değerini sağlayacak şekilde, çubuk LED barlar 4 mm kalınlığındaki alüminyum plaka üzerine monte edilmiş ve bu plakalar kurutucu kabinin üzerine yerleştirilmiştir. LED'lerin mesafeye bağlı aydınlatma (klüx) değerleri Cem marka DT-1309 tip lüxmetre ile ölçülmüş ve mesafeye bağlı olarak ölçülen değerler Tablo 2'de verilmiştir. LED'li kurutma sisteminde havanın kurutma bölgesine giriş sıcaklığı bölgenin gündüz sıcaklık ortalaması $30{ }^{\circ} \mathrm{C}$ olarak sabitlenmiştir. Kurutma kabini hava sıcaklığg ve fındık iç sıcaklığı T tipli termoelemanla (teflon 
izalosyonlu, Ø 0.010 inc ) ölçülmüş, data kart ile de zamana bağlı olarak sıcaklıklar kayıt altına alınmıştır.

Tablo 2. LED plakaların mesafeye bağlı aydınlatma değerleri

\begin{tabular}{cccc}
\hline & & \multicolumn{3}{c}{ İlişkili Renk Sıcaklığı (CCT) } \\
Mesafe & $\mathbf{3 0 0 0}$ K (klüx) & $\mathbf{4 0 0 0}$ K (klüx) & $\mathbf{6 5 0 0}$ K (klüx) \\
\hline $\mathbf{5} \mathbf{~ c m}$ & 89,5 & 85 & 78,8 \\
$\mathbf{1 0} \mathbf{~ c m}$ & 70 & 73,9 & 68,6 \\
$\mathbf{1 5} \mathbf{~ c m}$ & 68,1 & 62,6 & 63 \\
\hline
\end{tabular}

LED’in yaydığı ışınımın findık iç sıcaklığına etkisini belirlemek için yaş fındık 2 mm çapında delinerek termoeleman çifti fındığın ortasına gelecek şekilde yerleştirilerek fındığın iç sıcaklık değişimleri ölçülmüş olup, Şekil 2'de sisteminin fotoğrafı verilmiştir. Üç farklı kurutma yönteminin fındığın kuruma karakteristiklerine ( kütle -zaman değişimi) etkileri incelenmiştir. Kuruma işlemi fındığın nem değeri \%6 ya düşene kadar sürdürülmüştür.

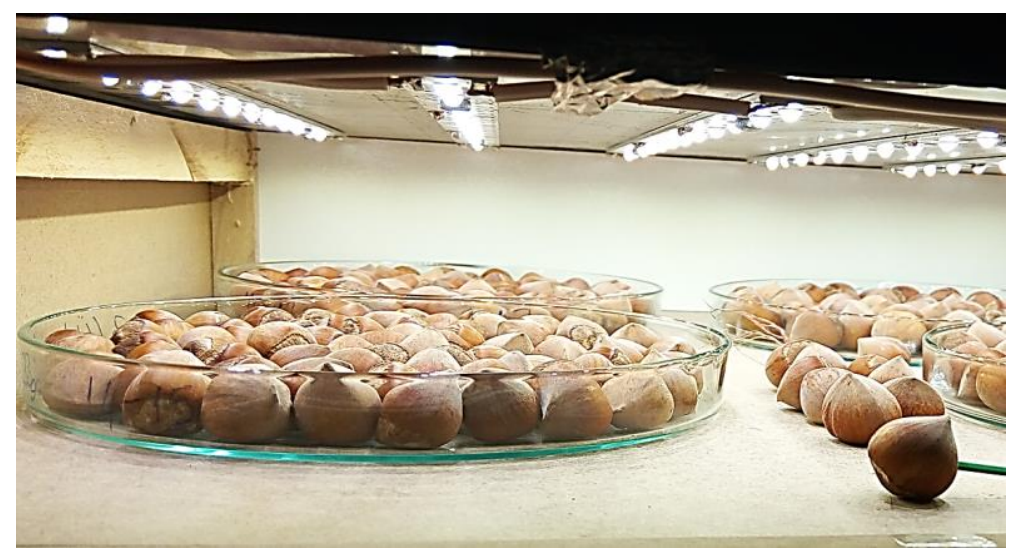

Şekil 2. Kabin ve fındık iç sıcaklıklarının ölçümü

\section{Sonuçlar ve Tartışma}

Yapılan deneysel çalışmalara dayanarak üç farklı kurutma ortamında üç farklı boyuttaki fındığın zamana bağlı kütle kayıpları elde edilmiştir. Ayrıca LED'li kurutma sisteminde hem LED'le 
fındık arasındaki mesafe artışının hem de renk sıcaklı̆̆ına bağlı olarak ışınımdan dolayı oluşan zamana bağlı sıcaklık değişim grafikleri verilmiştir.

$3000 \mathrm{~K}$ renk sıcaklı̆ğına sahip LED ile yapılan kurutmada findık boyutuna ve LED ile findık arasındaki mesafeye bağlı findığın zamanla kütle kaybı ve sıcaklık değişimleri Şekil 3'de verilmiştir. Şekillerden görüldüğü gibi findık boyutu artıkça findığın kuruma süreside artmaktadır. Fındık iç sıcaklı̆̆ı ortam sıcaklığından ışınım etkisinden dolayı her üç mesafe de fazladır.
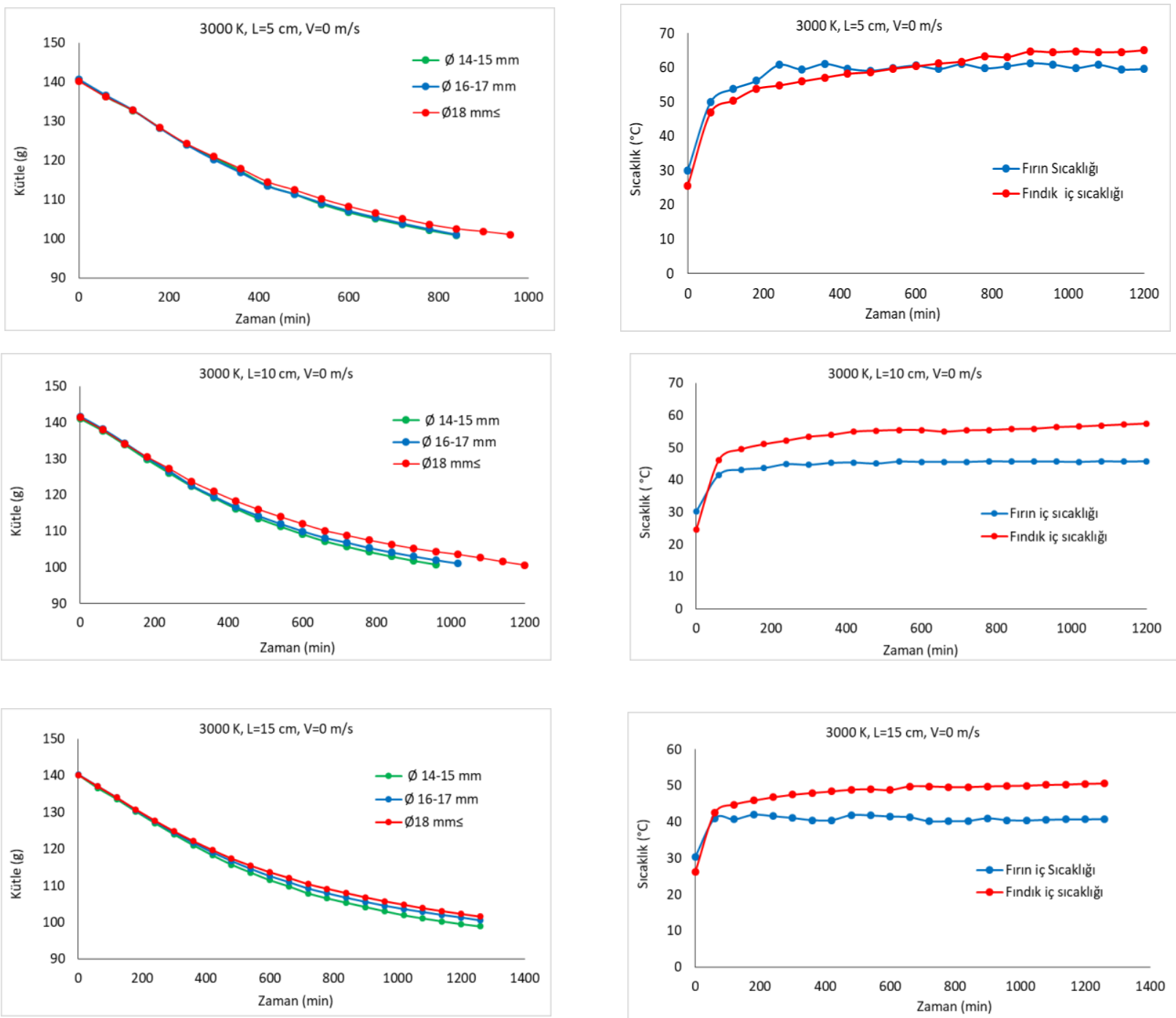

Şekil 3. LED-3000 K renk sıcaklığında yapılan kurutmada zamana bağlı kütle ve sıcaklık değiş̧imleri

$\mathrm{L}=5 \mathrm{~cm}$ mesafedeki kurutmalarda LED'lerin monte edildiği alüminyum plakadan kaynaklanan taşınım etkisi işınımla birlikte etkin bir rol oynamaktadır. 
Benzer şekilde $4000 \mathrm{~K}$ ve $6500 \mathrm{~K}$ renk sıcaklığına sahip LED ile yapılan kurutmada fındık boyutuna ve LED ile fındık arasındaki mesafeye bağlı findığın zamanla kütle kaybı ve sıcaklık değişimleri Şekil 4 ve Şekil 5'de verilmiştir. Şekillerden görüldüğü gibi findık boyutu artıkça fındığın kuruma süreside artmaktadır. $3000 \mathrm{~K}$ renk sıcaklığında yapılan kurutmaya benzer şekilde $4000 \mathrm{~K}$ ve $6500 \mathrm{~K}$ renk sıcaklığına sahip LED ile L=5 cm mesafede yapılan kurutma da fındık iç sıcaklığı taşınım ve ışınım etkisinden dolayı her üç mesafe de fazladır. L mesafesi arttıkça ortam ve fındık iç sıcaklıkları düşmekte, buna bağlı olarak da findığın kuruma süresi oldukça artmaktadır.
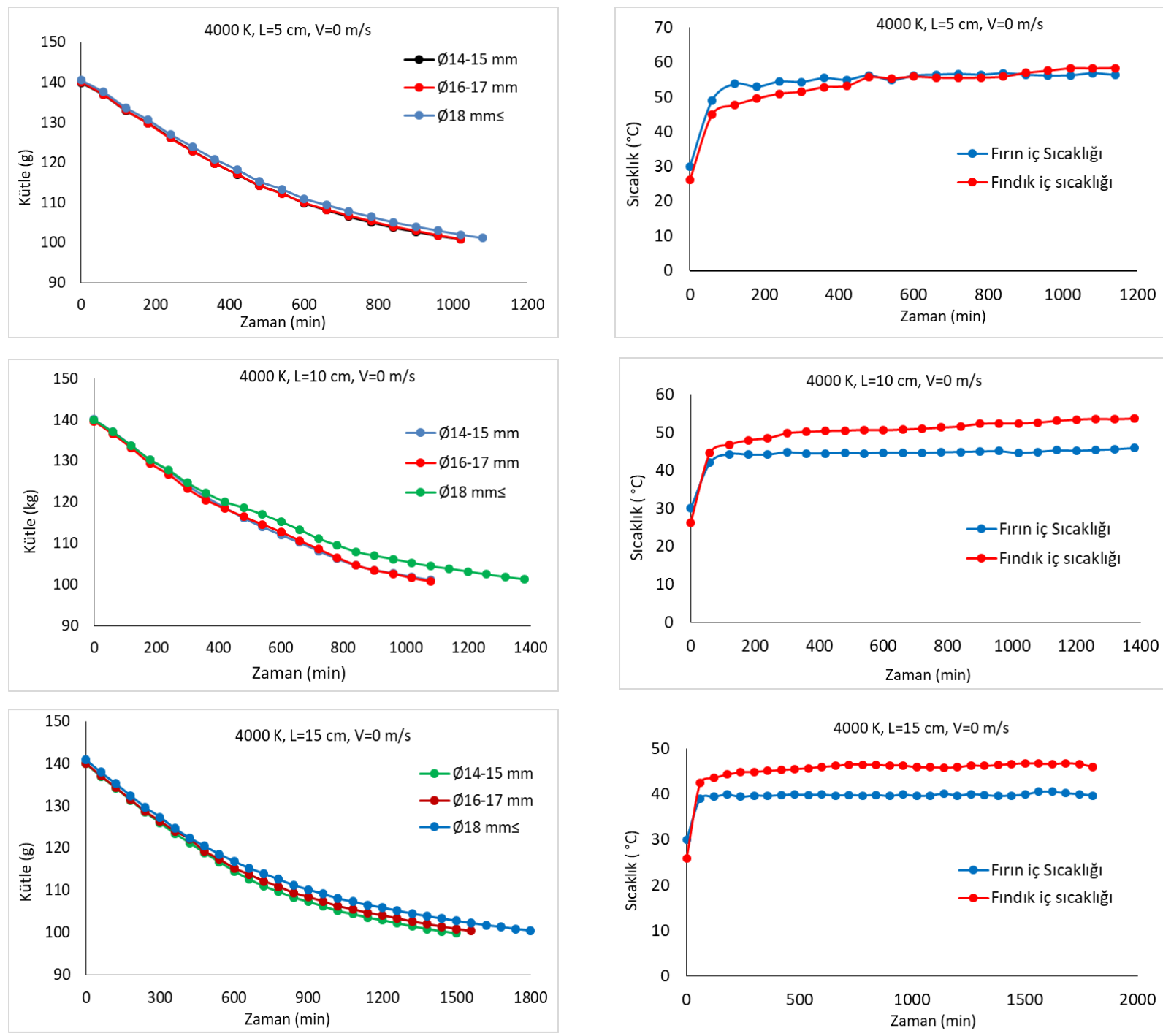

Şekil 4. LED-4000 K renk sıcaklığında yapılan kurutmada zamana bağlı kütle ve sıcaklık değiş̧imleri 

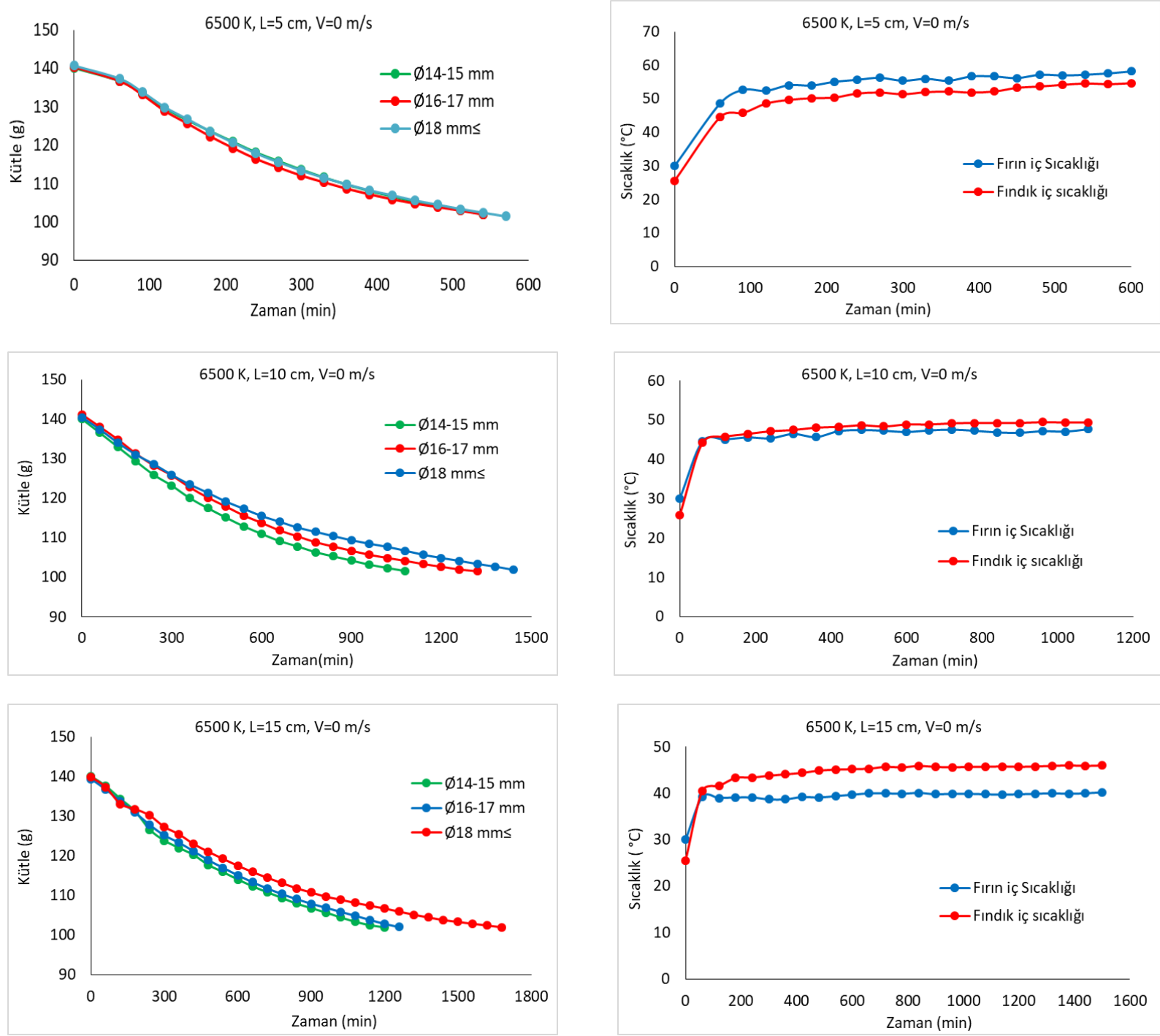

Şekil 5. LED-6500 K renk sıcaklığında yapılan kurutmada zamana bağlı kütle ve sıcaklık değiş̧imleri

LED ile yapılan findık kurutmayı etüvde kurutma ve Güneşte kurutma ile karşıllaştırmak için yapılan deneylerden elde edilen sonuçlara bağlı zamanla fındığın kütle kaybı grafikleri sırasıyla Şekil 6 ve Şekil 7'da verilmiştir. Şekillerden görüldüğü gibi fındık çapı 14-15 mm ve 16-17 mm iken kuruma süreleri yaklaşık aynı iken findık çapı $18 \mathrm{~mm}$ ve üstüne çıkıldığında kuruma süresi oldukça uzamaktadır. Bu durum Güneşte kurutmada yaklaşık 24 saat gibi oldukça uzun bir süredir. Güneşte kurutmada gündüz hızla findık kururken gece kuruma hızı düşmüş, bazı akşamlar ise findık kaybettiği nemi ortamdan geriye almıştır. 


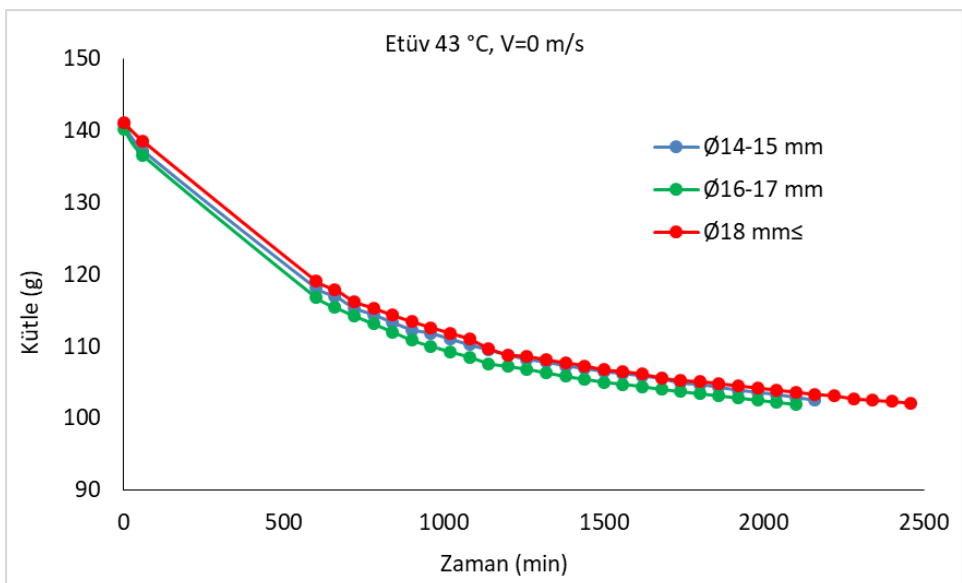

Şekil 6. Etüvde yapılan kurutmada fındık boyutuna bağlı zamanla fındığın kütle kaybı

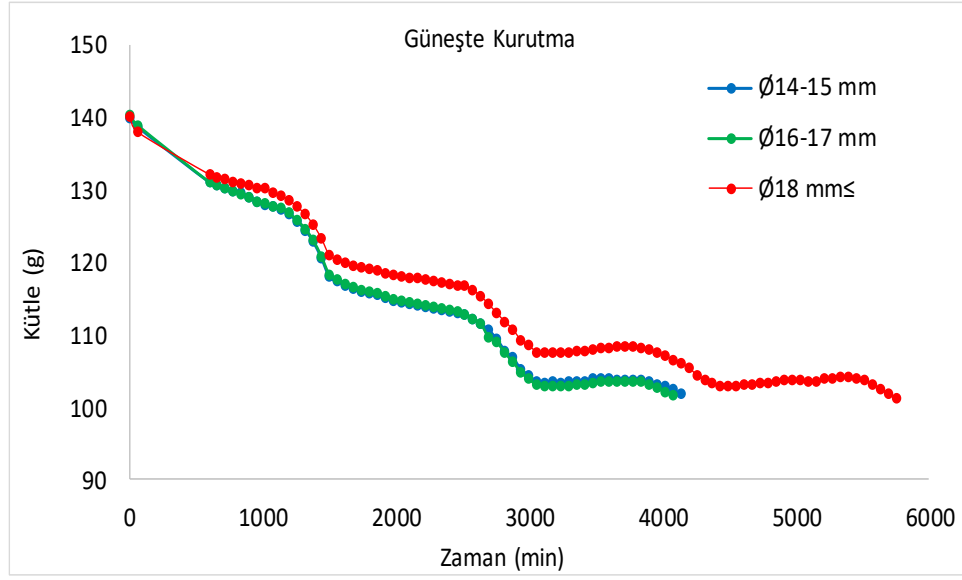

Şekil 7. Güneşte yapılan kurutmada findık boyutuna bağlı zamanla findığın kütle kaybı

Farklı kuruma ortamlarında Ø 16-17 mm boyutundaki findığın zamanla kütle kaybı Şekil 8'de verilmiştir. Burada en hızlı kuruma mesafesi olan $5 \mathrm{~cm}$ ve ortalama findık boyutu Ø 16-17 mm için kütle kaybı karşılaştırma grafiği verilmiş̧ir. Bu grafikte örüldüğü gibi en uzun kurutma süresi geleneksel yöntemle Güneşte kurutmada $\varnothing$ 16-17 mm boyuttaki findıkta olup 68 saattir. Ø 16-17 mm boyuttaki findığın Güneşte kurutma ile etüv, $6500 \mathrm{~K}, 4000 \mathrm{~K}, 3000 \mathrm{~K}$ 'de kurutma karşılaştırıldığında sırasıyla $\% 49, \% 74, \% 75$ ve $\% 88$ daha kısa sürede kurumaktadır. Bu süre fındık boyutu azaldıkça kısalmakta, findık boyutu ve mesafe artıkça artmaktadır.

LED ile findık arasındaki mesafeye ve LED renk sıcaklığına bağlı findığın iç sıcaklığının zamanla değişimi Şekil 9'da verilmiştir. Tombul findığın en fazla bulunduğu boyut (Ø 16-17 $\mathrm{mm}$ ) için bu grafikler verilmiştir. Maksimum findık iç sıcaklığı $65{ }^{\circ} \mathrm{C}$ ile $3000 \mathrm{~K}$ 'de gerçekleşmiştir. Renk sıcaklığı arttıkça LED’lerin ışınımla 1sı transferi etkisine bağlı olarak 
fındık iç sıcaklığı da azalmaktadır.

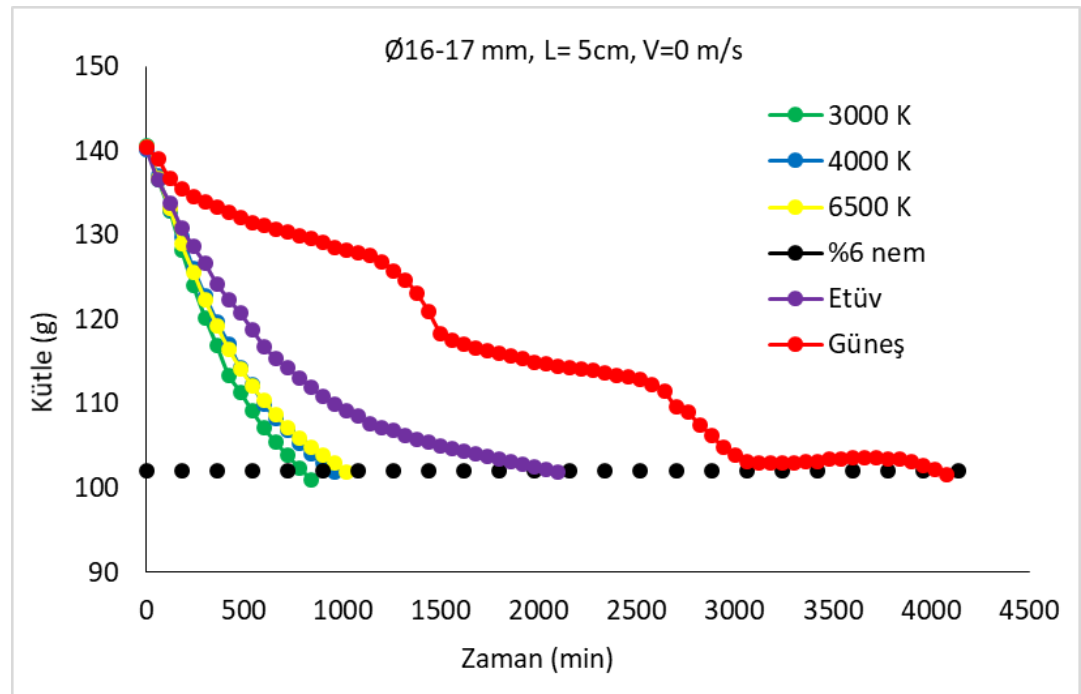

Şekil 8. Farklı kuruma ortamlarında fındığın zamana bağlı kütle kaybı

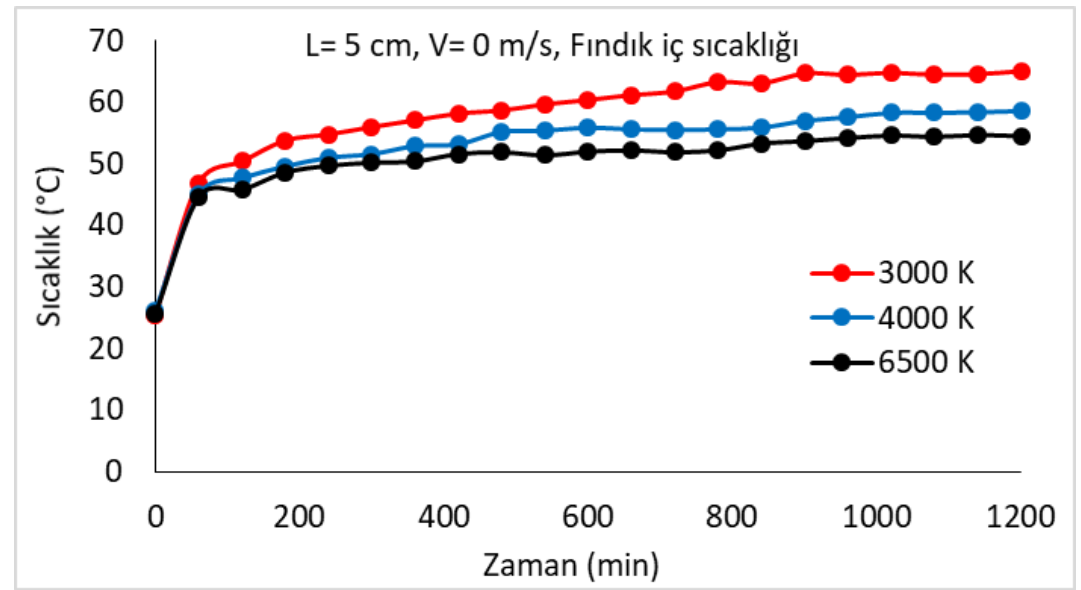

Şekil 10 LED renk sıcaklığına bağlı fındığın iç sıcaklığının zamanla değişimi

\section{Sonuçlar}

1. Doğal taşınımda $\mathrm{L}=5 \mathrm{~mm}$ ve $\varnothing 16-17 \mathrm{~mm}$ boyutundaki findığın Güneşte kurutma (4080 dk) ile etüv, $6500 \mathrm{~K}, 4000 \mathrm{~K}, 3000 \mathrm{~K}$ 'de kurutma karşılaştırıldığında findık, sırasıyla $\% 50,8$ (2010 dk), \%73,5 (1080 dk), \%77,9 (900 dk) ve \%82,4 (720 dk) daha kisa sürede kurumaktadır. Bu da kurutma süresine bağlı işçilik ve enerji maliyetini yaklaşık aynı oranda düşürmüştür. 
2. Doğal taşınımda fındıkla LED arasındaki mesafenin artı̧̧ıının etkisi en belirgin 4000 $\mathrm{K}$ renk sicaklığına sahip kurutma sisteminde gerçekleşmiş olup; $5 \mathrm{~cm}$ ve $10 \mathrm{~cm}$ mesafelerdeki kütle kayıpları $15 \mathrm{~cm}$ mesafeyle karşılaştırıldığında sırasıyla \%33 ve \%29 daha kısa sürede findık kurumaktadır. Üç farklı LED renk sıcaklığı için de LED ile findık arasındaki mesafe arttıkça kuruma süresi de artmıştır.

3. Doğal taşınımda findık boyutuna bağlı en kısa kurutma süresi (uygun sıcaklık aralığında) $3000 \mathrm{~K}$ renk sıcaklığı ve $\mathrm{L}=10 \mathrm{~cm}$ için 1080 dakika ile Ø14- $15 \mathrm{~mm}$ boyutlu findıkta gerçekleşirken, en uzun kuruma süresi $6500 \mathrm{~K}$ renk sıcaklığ 1 ve $\mathrm{L}=15 \mathrm{~cm}$ mesafe için $\varnothing 18 \mathrm{~mm}$ ve üstü boyutlu findıkta $1680 \mathrm{dk}$ olarak gerçekleşmiştir. Üç farklı LED renk sıcaklığı için findık boyutu arttıkça kuruma süresi de artmıştır.

4. LED'li sistemler 12 volt veya 24 volt ile beslendikleri için enerji verimliliği ve iş güvenliği ve işci sağlığı açısından caziptir.

5. LED'lerin ömrünün uzun ve sistemde çalışan karmaşık parçaların olmaması sistemin kullanım ömrünü artırmakta ve bakım onarım maliyetlerini de düşürmektedir.

\section{Referanslar}

[1] Bıçakçı M. Doğu Karadeniz bölgesinde havalı güneş kolektörleri ile prototip findık kurutma tesisatı tasarımı. Yüksek Lisans Tezi Karadeniz Teknik Üniversitesi Fen Bilimleri Enstitüsü. Trabzon: 1989.

[2] Demirtaş C. Fındık kurutma şartlarının belirlenmesi. Doktora tezi Karadeniz Teknik Üniversitesi Fen Bilimleri Enstitüsü. Trabzon: 1996.

[3] Olgun H, Rzayev P. Fındığın üç farklı sistemde güneş enerjisi ile kurutulması. Tr J Engin Environ Sci, Tübitak 2000;24:1-14.

[4] Özdemir M, Yıldız M, Gürcan S. T. Mekanik kurutmada hava sıcaklığının önemli Türk findık çesitlerinden tombul'un kalitesine etkisi. Gıda Dergisi 2002;35-9.

[5] Aktaş M. Isı pompası destekli findık kurutma fırınının tasarımı, imalatı ve deneysel incelemesi. Doktora tezi Gazi Üniversitesi Fen Bilimleri Enstitüsü. Ankara:2007.

[6] Akgün M, Şenyurt Ö, Kandemir L. Sıcak beyaz (sarı) renkli LED ile kurutmanın findığın (Corylus avellana L.) kuruma karakteristiklerine etkisi. Ordu Üniversitesi Bilim ve Teknoloji Dergisi 2017;266-74.

[7] Malekjani N, Emam-Djomeh Z, Hashemabadi S. H, Askari G. R. Modeling thin layer drying kinetics, moisture diffusivity and activation energy of hazelnuts during microwave-convective drying. International Journal of Food Engineering 2017;14(2).

[8] Giraudo A, Valentini N, Venturello A, Savorani F, Bertone E, Bonazzola G ve ark. Kinetic modeling of hazelnut drying: Effects of different cultivars and drying parameters. Journal of Food Process Engineering 2018;41(1):1-9.

[9] Turan A. Effect of drying methods on nut quality of hazelnuts (Corylus avellana L.). Journal of Food Science and Technology 201; 855(11):4554-65. 